\title{
Normative Tensions: European Sanction vs. ASEAN's Non-Interference in the Case of Myanmar
}

\author{
Verdinand Robertua \\ Universitas Kristen Indonesia \\ Cawang, jakarta Timur 13630 \\ Email: verdinand.robertua@uki.ac.id
}

\begin{abstract}
Abstrak
Paper ini berusaha menjelaskan relevansi antara kebijakan sanksi Uni Eropa dan kebijakan constructive engagement ASEAN. Teori NPE yang dikemukakan oleh lan Manner ini menjadi pisau analisis yang efektif untuk menjelaskan kebijakan sanksi Uni Eropa. Artikel ini akan mengelaborasi argumentasi Thomas Diez yang menekankan refleksi identitas Uni Eropa sebagai elemen utama teori NPE. Dalam penelitian ini akan dikaji pembentukan identitas UE yang dihadapkan berlawanan dengan ASEAN. Perubahan yang terjadi Myanmar akhir-akhir ini menjadi dasar bagi UE untuk menunda sanksi. Ini menjadi pertanyaan yang menarik karena berbagai laporan dari lembaga swadaya masyarakat internasional justru menunjukkan reformasi yang terjadi di Myanmar lemah dan tidak berkelanjutan. ASEAN muncul menjadi mitra utama Myanmar dalam demokratisasi dan pembangungan hak asasi manusia di Myanmar. Keywords: Normative Power Europe, EU sanction, ASEAN, constructive engagement, Aung San Suu Kyi
\end{abstract}

\begin{abstract}
This article attempted to explain the relevancy of European sanction policy and ASEAN's constructive engagement on Myanmar. In many case, normative power Europe theory which is pioneered by lan Manners, has been an effective tool to explain the EU's sanction policy. In this article, it will emphasize Thomas Diez's postulation of the reflexivity of the EU's identity as the main aspect of NPE. Consequently, it will elaborate on how EU's identity is constructed against ASEAN who adopted constructive engagement. However, recent change in Myanmar has provoked the EU to postpone their sanction. It is puzzling because many reports from International Non-Government Organizations show that the reform in Myanmar is weak and unsustainable. ASEAN emerged as important partner for Myanmar in driving democratization and human rights regime construction in Myanmar.

Kata kunci: Kekuatan Normatif Eropa, Sanksi UE, ASEAN, perjanjian konstruktif, Aung San Suu Kyi
\end{abstract}

\section{INTRODUCTION}

This article wants to highlight current change in the European Union (EU) foreign policy on Myanmar and the persistence of ASEAN's non-interference principle and assess its theoretical implication. More than 15 years, Myanmar has become the target of sanction from the United States (US) and the EU due to its poor performance on human rights and democracy. In other side, ASEAN, Myanmar's main trading partner, availability maintained constructive engagement strategy with Myanmar. Under Thein Sein's regime,
Aung San Suu Kyi is released and able to join byelection in April 2012. She and some NLD members won seats in parliament. Responding to the progress, ASEAN urged for western countries to lift out the sanction and the sanction is being lifted out. However, hundreds of political prisoners are still in jail and recently Myanmar army has done oppressive action toward Katchin ethic. Is Myanmar has done significant reform on human rights record? If not, what is the implication for normative power Europe theory?This 
article will be divided into four main parts: background of Myanmar and EU sanction on Myanmar, theoretical framework of Normative Power Europe, Effectiveness of the EU sanction, Construction of Normative Power Europe and lastly the implication of EU's policy to abandon the sanction.

\section{MYANMAR: A BRIEF HISTORY}

Myanmar was independent in 1948 and Military Junta has been in power since 1962. Myanmar army or Tatmadaw has significant influence in Myanmar regime and has shaped three form of military regime: first, Burma Socialist Party (BSPP) under Ne Win leadership in 1962 and second, State Law and Order Restoration Council (SLORC) commanded by Saw Maunin 1988 and lastly, State Peace and Development Council (SPDC) under Than Shwe leadership in 1997.

In 1987, in an effort to combat inflation and black market, the Burmese government demonetizes (http:// www.petersoninstitute.org/research/topics/sanctions/ myanmar.cfm,2012)

several denominations of bank notes. The action renders 60-80 percent of money in circulation worthless, triggering first protest demonstrations in more than a decade. Police mismanagement of a minor incident in Rangoon in March resulted in death of 42 students (Ibid). Pro-democracy demonstrations break out all over Burma; government responds with brutal crackdown on demonstrators, imposing curfew in major cities, detaining hundreds of protestors, closing universities.

In 1988, pro-democracy activists formed a political party named The National League for Democracy (NLD). Aung San Suu Kyi, one of the founders of NLD, emerged during the crisis as Myanmar's democracy icon. She is the daughter of Aung San, a pivotal figure in the Myanmar independence movement in the 1940s. Demonstration reached its peak on 8 August 1988 when 700,000 peoples gathered and took longmarchin Mandalay and Rangon for campaigning national-wide protest (Ibid). Military junta responded the protest by pouring armies to the street and took oppressive action toward protesters. It is reported that 3,000 persons killed, 1,000 persons injured and 2,000 activists detained (Ibid). This tragedy is known as 8-8-8 uprising.

To appease the conflict, government held national election for choosing parliament members. In 1990, NLD won the election. However, military junta didn't acknowledge the result and detained Aung San Suu Kyi and many pro-democracy activists and took over the government. Responding to power abuse by military junta, European Union imposed first sanction to Myanmar by banning military export from EU member states to Myanmar. In 1991, EU renewed her previous sanction and added sanction including the ban on military cooperation with Myanmar. These policies were not binding to all EU member states. However, in October 1996, EU for the first time was agreed to make common position imposing visa ban toward all Myanmar officials. They are not allowed to visit all EU member states. In 2004, EU added sanction including a ban on EU companies to invest in Myanmar companies that are controlled by military (Commission, 2013) and additional sanction is imposed by EU in 2007 of import ban of wood, steel and gem products from Myanmar.

In 2011, Myanmar government under Thein Sein released Aung San Suu Kyi from house arrest. In byelection April 2012, Aung San Suu Kyi was elected as parliament member. Thein Sein has adopted several policies including legislation permitting trade union, creation of Human Rights Commission,cease fire with Karen ethic. Responding to the progress, the US and the EU have lifted some sanction. Human rights activists were questioning the policy because Myanmar was not considered improving human rights regime significantly.

In June 2012 communal conflict between Rohingya and Rakhine ethic in Arakan province erupted. Ten Rohingya men were allegedly dragged from a bus in the western state of Rakhine and killed by a mob of ethnic Rakhine in response to the rape and killing of a Buddhist woman by three Rohingya men(Zheng, 2012). Although the specific cause of this 
conflict between the Muslim Rohingya and the ethnic Rakhine Buddhists is still unclear, this outbreak of violence in and near Rakhine state's capital city of Sittwe, has resulted in the death of at least 50 people and more than 2,500 houses and religious buildings set on fire, and more than 30,000 people forced to flee their homes (Ibid).UN reported that Rohingya people is the most persecuted minorities in the world (AFP, 2012). Government is not considered doing seriously in punishing the perpetrators and drafting peace resolution.

In December 2012 Asian Correspondent (Linn, 2012) reported that Myanmar army has launched comprehensive military operation against Katchin Independence Army, a paramilitary body of Katchin Independence Organization (KIO). According to media reports, there are more than 30,000 internally displaced persons (IDPs) in Burmese government controlled areas and over 60,000 IDPs are currently taking refuge in $\mathrm{KIO}$ controlled areas (Ibid). Several hundreds of civilians continue to escape their native places because they are scared of bullets, bombs, forced labors, rape, torture and other forms of violence. This humanitarian crisis raised global concern including from the United Nation, the EU and the US.

\section{RESEARCH QUESTION}

Some research has been made to evaluate the effectiveness of western states sanction to Myanmar. There are 6 countries imposing sanction to Myanmar up to date: the EU, the US, Canada, Japan, and Australia. Kryvoi (2007) and Eriksson(2005) mentioned that the sanction is failed to achieve its objectives due to significant influence by China, India, Thailand and Singapore toward Myanmar economic performances. Meanwhile Burma Campaign (2004 )mentioned that they are not serious in implementing the sanction. It is reported that the sanction is not targeting key sector of Myanmar economy. This article attempted to explain the purpose of EU's sanction on Myanmar using normative power Europe theory. It will look at the second purpose of EU's sanction which is the creation of EU's identity as novel actor. It will also discuss the implication of EU's policy to postpone sanction on normative power Europe theory. Is the theory still relevant to explain EU sanction policy toward Myanmar? This research is using qualitative methodology with the method of literature analysis by gathering reports and first and secondary sources from official EU websites, online news media and INGOs' reports.

\section{RESULT AND ANALYSIS}

NORMATIVE POWER EUROPE (NPE)

Ian Manners' (2002) seminal article of "Normative Power Europe: Contradiction in Terms?" has provoked a lot of discussion in explaining EU foreign policy. In 2007, scholars at the European Union Studies Association (EUSA) meeting voted Manners' article among the five most important, essential and seminal academic pieces published over the previous ten years.

Manners' concept of NPE became immensely popular in EU studies, and was also adopted in policy papers and public diplomacy. The self-identity of the EU, as laid out in the EU Security Strategy in 2003, is that it is a 'force for good'. Key EU representatives, such as European Commission President José Manuel Barroso, have enthusiastically endorsed the concept of NPE (Manners, 2008). Scholarly books and articles that apply, refine and build on the concept and foster a 'trans disciplinary approach to European studies' (Manner, 2009) are now proliferating (for example, Tocci et al., 2008; Whitman, 2011), not to mention the abundance of student essays and dissertations on the theme.

The idea of NPE is actually a response to the debate of EU's international role. In 1990s, there was a big question whether EU is military or civilian power. 20 years after EU's establishment, there was traditional conception of EU's international role as civilian power which was long on economic power and relatively short on armed forces. However it was then questioned when in $1999 \mathrm{EU}$ was creating European Security and Defense Policy (ESDP) and EU committed to have 60,000 military personnel for 
rapid reaction force (RRF) by the end 2003.

Manner criticized European scholars who are very active debating whether EU is a civilian or military power. He wrote:

One of the problems with the notions of civilian and military power is their unhealthy concentration on how much like a state the EU looks. The concept of normative power is an attempt to refocus analysis away from empirical emphasis on the EU's institutions or policies, and towards including cognitive processes, with both substantive and symbolic components (Manners, 2000 in Manners, 2002, p.239)

It was much said that NPE is on how the EU wants to promote and achieve European norms, such as human rights, climate preservation, and democracy. EU is seen as a novel actor but Diez said that rather than the zealous propagation of particular 'European' norms, it would be such a degree of reflexivity that would make 'normative power Europe' stand out. He explained:

"Young's contribution to the normative power debate illustrates that 'normative power' is not an objective category. Instead, it is a practice of discursive representation. From a discourse analytical point of view, the most interesting question about normative power therefore is not whether Europe is a normative power or not, but how it is constructed as one.(Diez, 2005, p.626)

According to NPE, the politics of the EU is the politics of creating or shaping the conception of the normal. It means that the EU will create what-isnormal in which the EU rivals are not in the circle of the EU's normal. For example, through series of conference and negotiation, EU is consistently campaigning climate change funds and emissions reductions in order to change the US behavior that is greed for natural resources and world's number one polluter. It adapts to Thomas Diez's postulation that EU identity is constructed 'against an image of others in the "outside world"' (Diez, 2005, p. 614) and thus depicts the process of identity formation as following the logic of identity and difference, in which the role of the 'other' is, in many case, played by the US.

Therefore, NPE also involved the politics of othering - the self and the other. Diez establishes four different modes of relationship between 'self' and 'other', according to the way the 'other' is represented vis-à-vis the depiction of the 'self': the other could be represented first, as an 'existential threat' (paradigm of securitization); second, as 'inferior' (paradigm of orientalism); third, as 'violating universal principles' (a variation of the paradigm of orientalism); and finally, as 'different' (refraining from making a value judgement) (Diez, 2005, p. 628).

In the case of EU sanction to Myanmar, inferior mode of relationship between the EU and Myanmar/ ASEAN is clearly seen from the EU's declaration and statement as well as bi-regional forum between ASEAN and the EU in ASEM (Asia Europe Meeting. The EU wants to shape the conception of the normal, which is sanction and democracy shall be placed toward Myanmar.

\section{INFERIOR IN VALUES}

The difference between Asian values and European values is an interesting topic. Asian values as a concept have been stressed by Southeast Asian leaders such as the former Prime Ministers Mahathir Mohammad of Malaysia, former President Soeharto of Indonesia and Lee Kuan Yew of Singapore. The 'founding father' of Singapore-Lee Kuan Yew has debated the differences of values in the society between east and west (Petersson, 2006). His argument is that in America there are guns, drugs and violent crime. People do not dare to go out in the middle of the night (Ibid). The reason according to Lee is that humans have been granted too many rights at the expense of the society. Too much freedom, the argument goes, can disrupt the development and lead to social conflict. Suharto have either resisted the universality of Western concepts of democracy, rights and law or suggested that there are different non-liberal but equally valid understandings of these terms (Jones, 1997: 5-55 in Mukherjee, 2010). In one speech, Former Myanmar President Than Shwe blamed the West for using 
democracy and human rights as an excuse for other intentions, arguing that Asian standards of democracy cannot be the same as the Western standards (Petersson, 2006). Other arguments from Asian leaders are that economic growth is the most important aspect of the society and growth will eventually lead to democratic developments. East Asian politicians argued that it was predominantly their Islamic-Confucian cultural values that were acting as the driving force behind Asia's tremendous economic success during the 1990s. Western arguments, on the other hand, stress the importance of democracy as a base for economic growth, and often discharge the Asian value argument as a justification for suppressive behavior by authoritarian governments.

The liberal foundations of the European project are reflected in the political culture of the EU based on democracy, rule of law, freedom of expression, some form of free trade, transnational co-operation, and shared normative framework finds its expression in the acquis communautaire and in the admission of new Member States. The presence of regional supranational institutions and international non-governmental organizations (INGOs), among others European Court on Human Rights, European Court of Justice (ECJ), European Parliament, and European Commission are also main factors of establishing the EU as the strongest human rights regime in the world.

Liberal values are also reflected in EU foreign policy. There are five purpose of EU foreign policy and one of them is "to develop and consolidate democracy and the rule of law, and respect for human rights and fundamental freedoms" (Council, 2013).During 1990s, human rights, democracy, and later governance became increasingly important determinants in the European Union's external relations as a whole. It is presumed that ensuring human rights protection and democracy in the nonEU countries can help the EU to achieve stability and peace in the European continent and in the world. The most concrete examples are the EU's policy in enlargement and European Neighborhood Policy (Hettne, Söderbaum and Stålgren, 2008, p.29-30).
The EU formulated a large number of specific human rights and governance-related conditions and criteria for its development assistance and trade policies. The EU is the biggest aid donor in the world which nearly three times US' official development aid (OECD, 2007). Since 1995, over twenty agreements have been signed that contain the human rights clause and applies to over 120 countries (Smith, 2003, pp. 111-112).

The EU also resorted to the application of sanctions against countries that it deemed to have disrespected human rights, democracy or governance norms. As seen in the below graphic, more than 50\% of the EU sanctions are related to human rights and democracy.

\section{Image 1. Factors of the EU sanctions on Non-Members Period of 1981-2004.}

\section{Rest of The World}

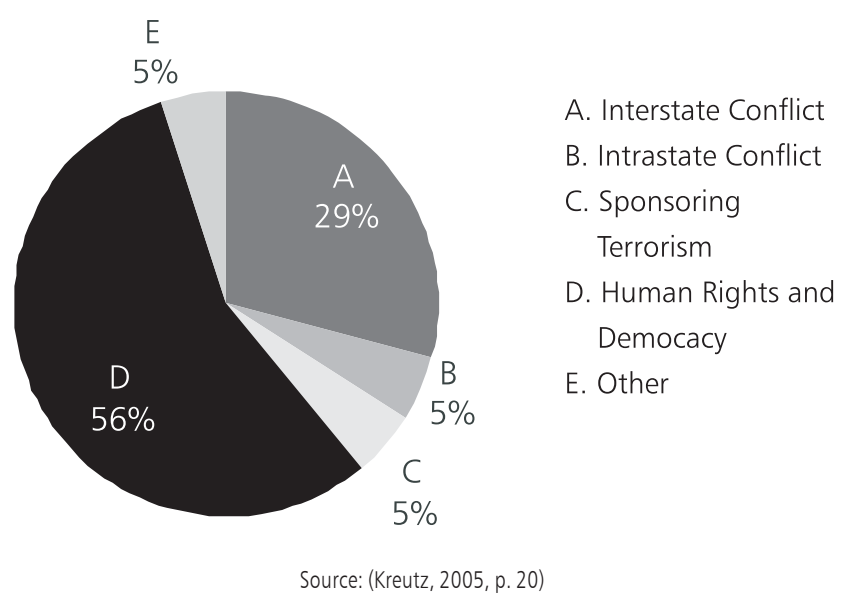

\section{NPE IN EU'S SANCTION ON MYANMAR}

In the case of EU sanction to Myanmar, sanction is the main strategy in constructing Normative Power Europe. Human rights consideration is explicitly mentioned in all European Council's documents on sanctions toward Myanmar. For example, in the common position 1996, it is written:

"... EU is concerned at the absense of progress towards democratisation and at the continuing violation of human rights in Burma/Myanmar. The European Union 
Table1.Summary of EU Sanction to Myanmar1996-2012

\begin{tabular}{|c|c|}
\hline COMMON POSITION & SANCTION \\
\hline $\begin{array}{l}96 / 635 / \text { CFSP } \\
28 \text { October } 1996\end{array}$ & $\begin{array}{l}\text { - All personnel military working in Myanmar diplomatic offices in EU areas went } \\
\text { sent out } \\
\text { - Arms embargo Humanitarian and development aid suspension } \\
\text { - Visa ban for all military senior } \\
\text { - Suspension of bilateral summit in Myanmar (Sipri, Common Position on } \\
\text { Burma/Myanmar 1996/635/CFSP, 1996) }\end{array}$ \\
\hline 2000/346/CFSP & - Renewal ofCommonPosition96/635/CFSP \\
\hline 26April2000 & $\begin{array}{l}\text { - Freezing assets and funds of military officers in EU financial institutions } \\
\text { - Ban on arms export to Myanmar (Sipri, Common Position 2000/346/CFSP, } \\
\text { 2000) }\end{array}$ \\
\hline 2003/297/CFSP & - Renewal ofCommonPosition96/635/CFSP \\
\hline 28April2003 & $\begin{array}{l}\text { - Additional military senior names for asset freezing and visa ban (Sipri, } \\
\text { Common Position 2003/297/CFSP, 2003) }\end{array}$ \\
\hline 2004/423/CFSP & - RenewalCommonPosition2003/297/CFSP (Sipri, Common Position \\
\hline 26April2004 & 2004/423/CFSP, 2004) \\
\hline 2005/340/CFSP & - Renewal CommonPosition2004/423/CFSP \\
\hline 25April2005 & $\begin{array}{l}\text { - Investment ban to Myanmar state-owned companies Myanmar (Sipri, } \\
\text { Common Position 2005/340/CFSP, 2005) }\end{array}$ \\
\hline 2007/750/CFSP & - Import ban on wood, gem and steel from Myanmar \\
\hline 150ktober2007 & $\begin{array}{l}\text { - Renewal of CommonPosition2004/423/CFSP (Sipri, Common Position } \\
\text { 2007/750/CFSP, 2007) }\end{array}$ \\
\hline 2012/225/CFSP & - Suspension of all ban for a year except arms ban (Sipri, Common Position \\
\hline 26 April 2012 & 2012/225/CFSP, 2012) \\
\hline
\end{tabular}

recalls its great concern at the failure of SLORC to respect the results of the May 1990 elections and the sunsequent maintenance of the military rule."(Sipri, 1996)

Since 1996 to 2011, EU has continuously increased the weight of sanctions. However, in 2012, the EU has postponed all sanction, excluding arms sanction.

\section{NPE'S LIMITATION: POWER ASYMMETRIES}

Power asymmetries are related to EU's roles, power and influence. Power imbalances are endemic between parties involved in a conflict as well as between the EU and one or both conflict parties. This asymmetry in power relations in turn affects processes and any desired outcomes that constructions of NPEU are aimed at. EU normative power can be weakened if other actors who have different values and norms have bigger roles and influence to the target state.

In the wake of the May 2008 Cyclone Nargis, the military regime was faced with a complex humanitarian emergency. Initially the regime was reluctant to grant access to international organizations and other bodies (Cook, 2010). However, ASEAN was able to facilitate greater access for international humanitarian agencies to those affected by the natural disaster through the Tripartite Core Group (TCG), an ASEAN-led mechanism. The TCG was formed after the May 2008 special ASEAN meeting in Singapore and the UN-ASEAN pledging conference in Yangon to 
'facilitate trust, confidence and cooperation between Myanmar and the international community (Ibid). The TCG offered a mechanism through which visas were quickly processed for UN officials and foreign aid workers; it assisted the entry and deployment of WFP helicopters; and facilitated the collection of data from affected areas. Meanwhile, the EU can hardly engage with Myanmar in Cylone Nargis. As the leading international actor in emergency disaster aid, EU was eager to channel substantial aid to Myanmar. However, the initial response of the military regime in Myanmar was to block and delay the EU aid (Abramowitz \& Pickering, 2008). As a result of EU hegemony toward Myanmar, the exclusion of humanitarian assistance highlights a way that the EU can assist those affected by the Cyclone.

Table 2. Myanmar Trading Partner in 2011

\begin{tabular}{llll} 
EXPORT & \multicolumn{3}{l}{ IMPORT } \\
PARTNERS & & PARTNERS & \\
Thailand & $36.7 \%$ & China & $38.8 \%$ \\
China & $18.8 \%$ & Thailand & $22.6 \%$ \\
India & $14.1 \%$ & Singapore & $9.7 \%$ \\
Japan & $6.6 \%$ & Malaysia & $4.5 \%$ \\
& & Japan & $4.1 \%$ \\
\hline
\end{tabular}

Source: (Factbook, 2013)

The EU is hardly influence Myanmar due to its lack of economic importance on Myanmar. As seen in table 2, ASEAN, China and India are top three important trading partners. Eriksson (2005) stated that there would be more information available which could decrease the likelihood of the target getting circumventing the EU sanctions. Kryvoi (2007) stated that Myanmar have a powerful non-Western "older brother", who turns a blind eye to violations of labor rights and human rights violations in general and provide economic support. China is the key trade, investment and political partner of Myanmar.For instance the Burmese ambassador to London has once said that "we are not worried about US and European sanctions, as trade with India, China and Thailand is already good"(News, 2003).

\section{NPE LIMITATION: CONFLICTING WITH MEMBER STATES INTEREST}

So many times EU policies don 't reflect EU's norms and values. Political lobbying and economic considerations of member states has created obstacles in the implementation of normative power Europe. Indeed conflicting with member states interestis unavoidable due to different interest between each EU member states.

In EU sanction toward Myanmar, France is a country who has conflict of interest in the EU policy. The main factor of French resistance is that French Total Oil has large investment in Myanmar. Burma Campaign UK has published a report that Total Oil has successfully lobbied French government to persuade Myanmar government to secure their business objective in Myanmar (Burma Campaign, 2005).Total Oil is EU biggest investor in Myanmar and has large concession for gas exploitation and exploration which located in Yadana project. Burma Campaign UK reported that Yadana project has produced incomes for military junta amounted 450 million US Dollar every year (Ibid). Not only Yadana, Total Oil also got concession for gas exploitation in Sein with contruction cost amounted 40 million US Dollar.

Burma Campaign UK reported some evidences that Total Oil has lobbied French government to secure their business worldwide:

1. Total Oil received strong political support from Chirac regime. Former French President Jacques Chirac and Former Total Oil CEO Thierry Desmarest have been travel companions on numerous official foreign trips since the mid-1990s. They have travelled together to Algeria(2003) and Libya(2004). In June 2004, Chirac awarded Thierry Desmarest one of France's highest accolades, the Legion of Honour, for distinguished service to France.

2. French government has defended Total Oil in many lawsuits toward Total Oil in many courts of 
countries including Belgium, France and United States of America. In one of hearing in the US court, French government mentioned:

"respect fullyo bjects to the exercise of personal jurisdiction by this court over, a corporate citizen of France, on the ground that it would conflict with the sovereignty and laws of France. Maintenance of this action against in the United States courts will conflict with France's foreign policy interests". (Ibid)

In the case of EU sanction toward Myanmar, French government has declared its position to against full ban toward Myanmar. Burma Campaign UK has published on how French diplomat has protected Total Oil from investment sanction toward Myanmar in 2004. In October 2004, European Union has considered to impose targeted sanction to European companies in Myanmar. International NGOs urged $\mathrm{EU}$ to take this sanction because previous sanction has not been effective to change Myanmar and consequently, this sanction will have significant impact to Total Oil operation. Chirac expressed his concern that EU sanction should not endanger European companies' activities in Myanmar including Total Oil. BBC International has published his comment:

“... French President Jacques Chirac seemed to cast doubt on their effectiveness, saying he hoped the EU's sanctions policy would not damage the operations of the French oil firm, which has large investments in Burma." (Ibid)

After intensive lobbying, the sanction plan is being revised. EU imposed sanction to European companies not to give loan to Myanmar companies.

\section{NPE IN ACTION: THE EU, ASEAN AND MYANMAR}

Despite its limitation as explained above, NPE is still valid. Without showing much flexibility, the EU maintained its tough stance against Burma, and wanted to exclude Burma's participation in the ASEM (Asia-Europe Meeting). ASEAN resisted for applying hard stances on Myanmar and prefer giving statement on Myanmar issue. The EU strongly opposed Myanmar's entry into the ASEAN and refused to have a dialogue in ASEM in the presence of officials from the military junta. ASEAN on other hand defended its new member, arguing that the ASEM process should continue to follow the norms of ASEAN and the ARF (Asia Regional Forum). European and Asian foreign ministers had agreed on this approach only months before Myanmar's entry. The Joint Declaration of the 12th ASEAN-EU Ministerial Meeting in Singapore in 1997 stressed that security cooperation should be deepen in issues of common concern and that the dialogue should not stop because of differences in certain areas (Cook, 2010).

This hostility created inability to reach an agreement and led to the cancellation of the Joint Cooperation Committee meeting in 1997. The ASEM II meeting in London 1998 following the economic crisis was met with great controversy. Since the UK did not grant any visas for Myanmar officials, they were automatically left out from the meeting. ASEAN threatened with a complete boycott. The EU was putting a strong point on ASEM being more than just economics, and that political sensitivities had to be dealt with on a ministerial level. The attempt to exclude Myanmar failed and even if officials from the military junta did not attend the meeting, it was agreed on that the ASEM process would be an informal forum where all participants will have equal status. In a very diplomatic statement by the Chairman for the ASEM II meeting, it was declared that ASEM do not need to be further institutionalized and is an informal process.

In order "not to let the issue of Burma/Myanmar hold the ASEAN-EU dialogue hostage" (a criticism raised against Europe by ASEAN members desperately in need of support after the 1997 crisis), the first Foreign Ministers' Meeting with Burmese representatives was held in Vientiane in December 2000. However several EU members sent only a low-level delegation. A "diplomatically correct" declaration was made but Burma was still denied access to the 1980 ASEAN-EU Economic Cooperation Agreement, thus refusing Rangoon access to any developmental programmes. 
Since then, the problem and deadlock in the ASEM process were consistent in the ASEAN-EU relationship. In the absence of goodwill from the junta and with an EU affixed to its prerequisites, two ASEM ministerial meetings were cancelled (July and September 2004). During the ASEM Foreign Ministers Meeting in Ireland to discuss the enlargement of the ASEM process in 2004, the EU reiterated its stances by lying down conditions calling for the release of Aung San Suu Kyi, free participation of the National League for Democracy and other elected representatives in the National Convention, etc, in return for Burma's participation in the ASEM process (Rocher, 2012).

Obviously, Burma remained a contentious issue and, as a continuing irritant, it became a stumbling block to inter-regional cooperation. Human rights issue in Myanmar is the main obstacles of the creation of EU-ASEAN Free Trade Area. Southeast Asian countries have been remarkably successful in penetrating EU markets and in diversifying the composition of their exports to the EU. By the end of the century, ASEAN trade with the EU exceeded that of the 70 ACP (Africa, Carribean, and Pacific) countries (Kettunen, 2004). In the 15-year period immediately preceding the 1997 Asian financial crisis, the EU enjoyed a trade surplus with ASEAN in only two years, which are 1985 and 1995 (Commission, 2006). In 1998, ASEAN's surplus was multiplied by nearly ten times from its level in 1997. By 2005, EU exports to ASEAN amounted to EUR44.888 billion, but its imports from ASEAN totaled EUR70.520 billion leaving a trade deficit of EUR25.632 billion. The average deficit from 2001 to 2005 was EUR25 billion (Centre, 2006). Hence, when in 2002-2003, several ASEAN membersrequested FTA negotiations and the European Commission refused the proposals. The European Commission claims that economic criteria, such as market potential and protection against EU export interests, are not the only criteria for selecting FTA partners. Political criteria - the human rights record and democratic credentials - are also allegedly taken into account(Robles, 2008).
As was to be expected, ASEAN, which has steadfastly refused to take action against Myanmar, was reported as insisting on region-to-region negotiations as a means of enhancing ASEAN's bargaining power. The alternatives to the ASEAN's position would have entailed either negotiating with individual ASEAN members, which would have been unacceptable to ASEAN, or not entering into an FTA, which would have been unacceptable to both (Nation, 2007).

In July 2006, the EU's Trade Counselor in Thailand admitted that political reform in Myanmar was the main issue that the $\mathrm{EU}$ had to consider as it decided whether to proceed to FTA negotiations (Nation, 2006). A year later, the EU apparently agreed to the ASEAN format: in May 2007, the EU's Trade Commissioner, while insisting that the EU position on Myanmar had not changed, agreed to initiate FTA negotiations with ASEAN, without excluding Myanmar (Bernama.com, 2007). Bloody monk protest in Myanmar in September 2007 changed the whole direction of the EU-ASEAN FTA. The European Parliament, the European Council and European NGOs to the EU were to impose new sanctions and stop FTA talks.

The September 2007 crackdown against monks the so-called Saffron Revolution - was unsurprisingly followed by strong condemnation by the EU and the international community. The resolution adopted by the European Parliament (Parliament, 2007) "applauded the courageous action of the Burmese monks and tens of thousands of other peaceful demonstrators in confronting the antidemocratic and repressive regime and utterly condemned the brutal response by the Burmese authorities." The European Parliament "expressed its horror at the killing of peaceful protestors, insisted that the security forces return to barracks and called for recognition of the legitimacy of the demands" (Ibid) being made as well as for the release of arrested demonstrators and other political prisoners, including Aung San Suu Kyi. It approved a brief but far-reaching list of demands, some directed at the Burmese government but others aimed at the international community, including China. These were the 
first targeted sanctions that would actually have an impact on the regime and its cronies. "In view of the seriousness of the current situation and in solidarity with the people of Burma/Myanmar, the EU deems it necessary to increase direct pressure on the regime through stronger measures" (Council, 2007) declared the Foreign Ministers in a joint statement.

In response, ASEAN member states sent request to Myanmar by using the strongest use of language since Myanmar joined ASEAN. ASEAN member states clearly and strongly expressed outrage at Myanmar's violent repression. Indonesia called on Myanmar to "exercise maximum restraint and desist from any acts that could cause further violence" (Kittisereechai, 2008). Singapore's Foreign Minister, George Yeo, acting as Chair of ASEAN, in a formal statement expressed the collective "revulsion" to Myanmar Foreign Minister Nyan Win (Yeo, 2007). In April 2008, the European Parliament called on the governments of the EU to consider more targeted sanctions, such as a comprehensive ban on new investments and an embargo on trade in key commodities that provided significant revenue to the military government. Furthermore, it urged the EU to campaign for a worldwide arms embargo on Burma.

Evidence for internal division onASEAN's position over Myanmar issue is seen in the ASEAN's split decision in 2005 to deny Myanmar the chair of the organization. The chairmanship of ASEAN is alphabetically rotated, and the Philippines will take the place of Burma, which is listed under the name of Myanmar. The Thai Foreign Minister Kantathi Suphamongkohn was clearthat "we [ASEAN] had been informed by our colleague. Foreign Minister U Nyan Win of Myanmar, that the Government of Myanmar had decidedto relinquish its turn to be the Chair of ASEAN in 2006 because it wanted to focus its attention on the on-going national reconciliation and démocratisation process" (Osman, 2005). However it is reported that there have been divisions over the issue within the 10-member ASEAN body itself. Burma's loyal supporters are mainly the newer members of the group - Laos, Cambodia and Vietnam. But
Indonesia, the Philippines, Malaysia and Singapore had urged ASEAN to break with their stance of noninterference and send a message to Rangoon that it must begin the real work of democratic reform(News, 2005). In the end, they shared Burmese view.

\section{MYANMAR'S REFORM: IS IT SUSTAINABLE AND IRRE- VERSIBLE?}

After the adoption of a new constitution in 2008, an election was called on 7 November 2010. These general elections constituted the fifth step on a sevenstep roadmap to democracy. They resulted in a victory for the military-backed "Union Solidarity and Development Party" and a new government at the end of March 2011.

Despite Western scepticism of Burma's first poll in 20 years (most of the leaders of European countries have responded to the result of the elections with condemnation, regarding them as not free and fair), ASEAN welcomed November's "conducive and transparent" election as it has supported the slow transition in a perseverant, yet discreet manner (Haacke, 2008). For the first time, ethnic minorities have a legal framework, allowing them to be represented in Parliament. Echoing a joint declaration by major ethnic political parties, ASEAN called for the lifting of sanctions enforced by the United States and European countries.

In November 2010, 1 week after the contest, Aung San Suu Kyi was released and, in the following months, met different ministers. Surin Pitsuwan, Former Secretary General of ASEAN, welcomed the "reconciliation gesture". Later, taking advantage of the reform process (amendments to the party registration law of 2010), NLD senior leaders decided to register as a new political party, which means that they can field candidates for the next election, including Aung San Suu Kyi herself.

On 30 March, Than Shwe resigned from his position as Head of State and Thein Sein became the president of Burma. A dialogue between the government and Aung San Suu Kyi was initiated when she was invited to Naypyidaw by the new president. 
In November 2011, when she met with representatives from the EU, Aung San Suu Kyi pleaded for a visit byWunna Maung Lwin, the current Burmese Foreign Minister to Brussels (the minister had already gone to Washington and received Secretary of State Clinton in December 2011). And at the ASEAN Bali Summit of November 2011, Burma was approved to chair the Association in 2014. David Lipman, the EU's Bangkok-based ambassador to Myanmar stated that responding to drastic change in Myanmar, the EU will review EU's policy on Myanmar (Robinson, 2012). In April 2012, the EU has postponed all sanction except arms embargo.

However, NGOs and ethic activists are against EU's decision to postpone the sanction. There are some reports showing government failure in implementing its promise and even harming Burmese society through negligence on sectarian violence and arms attack.

Regarding media freedom, Paris-based press organization Reporters Without Borders have reported that media reform has not been effectively implemented as promised. On August 20, 2012 the government announced the end of prior censorship for all of Burma's weeklies, ending a 48-year-old practice. However, most journalists say this has not meant a radical change in their activities(Ismail, 2012). Some claimed that they have not seen any radical evolution in the content of the weeklies since the lifting of prior censorship. Myanmar Independent editor Ma Thida said some reporters pay more attention now to what they write than during "the era," a term often used in interviews to refer to the period when prior censorship was in force, suggesting that, although recent, journalists regard it as a thing of the past (Ibid, p.17).

"Before, we could write what we wanted and we waited to see if it would obtain the PSRD's (Ministry of Information's Press Scrutiny and Registration Division) approval but now we must go to press knowing that if we cross the line, we will pay the consequences," Ma Thida added (Ibid, p.17). Since the abolition of prior censorship, journalists have being paying much more attention to the content they publish or have been censoring themselves for fear of government reprisals. The editors of non-political publications, the first to benefit from the lifting of censorship, were the first to note this and it has been repeatedly confirmed since the start of the year.

At least four lawsuits were brought against privately-owned weeklies from January to August 2012, mostly by government officials (Ibid, p.17). Modern Weekly and one of its reporters, Thet Su Aung, were sued construction ministry engineer in January over a November 2011 article about the poor condition of a road in the Mandalay area. A March 2012 article in The Voice about alleged corruption within the government elicited a libel suit from the ministry of mines on 20 September 2012, a month after the end of censorship.

Although it no longer screens content before publication, the PSRD still has an effective mechanism for pressuring the print media. As it registers newspapers and controls publication licences, it can suspend a newspaper whenever it likes for publishing "forbidden" content. Just two weeks before censorship was lifted, two weeklies, The Envoy and The Voice, were suspended indefinitely for "violating 2011 Order No. 44" and for "contravening PSRD regulations," namely, publishing articles that had not received prior approval (Ibid, p.19).

Despite of Thein Sein's commitment for cease fire with ethnic minorities, Myanmar army has not stopped attacking ethnic minorities including Rohingya and Kachin. In July 2010, there was an outrage in Arakan states that resulted to five death and thousands of people flee to Thailand and other ASEAN country. Human Rights Watch reported that there is negligence of government toward this sectarian conflict and not protecting the minorities. Drawing on 57 interviews conducted in Burma and Bangladesh with Arakan, Rohingya, and others, this report describes the initial events, the acts of violence that followed by both Arakan and Rohingya, and the role of state security forces in both failing to intervene to stop sectarian violence and directly participating in abuses (Watch, 2012). It examines the discriminatory forced relocations of Rohingya by the Burmese govern- 
ment from an Arakan population that feels long ignored.

Witness after witness described to Human Rights Watch how the Burmese authorities failed to provide protection to either side in the early days of the violence and that Arakan and local security forces colluded in acts of arson and violence against Rohingya in Sittwe and in the predominantly Muslim townships of northern Arakan State (Ibid).

Not only with Rohingya, Myanmar army also took offensive action against Katchin ethnic. Media (Fuller, 2012; Linn, 2012) has reported that since December 2012, Myanmar army has executed comprehensive military operation against Katchin Independence Army, a paramilitary body of Katchin Independence Organization (KIO). It was estimated that there are more than 30,000 internally displaced persons (IDPs) in Burmese government controlled areas and over 60,000 IDPs are currently taking refuge in KIO controlled areas (Linn, 2012). Several hundreds of civilians continue to escape their native places because they are scared of bullets, bombs, forced labors, rape, torture and other forms of violence. This is not the first case of army attack. Human Rights Watch has reported that the Burmese government has committed serious abuses and blocked humanitarian aid to tens of thousands of displaced civilians since June 2011, in fighting in Burma'snorthern Kachin State (Watch, 2012). The 83-page report, “'Untold Miseries': Wartime Abuses and Forced Displacement in Burma's Kachin State," describes how the Burmese army has attacked Kachin villages, razed homes, pillaged properties, and forced the displacement of tens of thousands of people. Soldiers have threatened and tortured civilians during interrogations and raped women. Thearmy has also used antipersonnel mines and conscripted forced laborers, including children as young as 14 , on the front lines. If there is no immediate action done by current regime, the humanitarian crisis will be escalated to unprecedented level.

The lifting of sanctions on Burma delegitimizes ethnic nationalities' demands for a cessation of hostilities in Kachin state, and prematurely rewards the Burmese regime while the military undertakes a clear escalation of violence. The absence of sanctions removes the motivation for the government to engage in further and serious negotiations with ethnic groups as well as political reform leading towards the 2015 election. The removal of sanctions condones the violence, exacerbates the conflict, destabilizes the negotiations, and sets back the peace process.

\section{CONCLUSION}

This research concluded that, before the sanction is lifted out, the EU successfully projects of itself in the international arena. Through sanction, EU managed to export what the EU is. Although there is inconsistency between internal and external planes, $\mathrm{EU}$ is considered as novel actor that campaign for 'utopian normativity' (Nicolaidis \& Howse, 2002, p. 789) and the 'missionary zeal' (Diez, 2005, p. 623). EU sanction is symbolic action picturing EU's identity as human rights champion, compare to ASEAN who adopted a more flexible and friendly policy. However, in the beginning of 2012, NPE become obsolete. The hegemony of sanction policy is being challenged and EU instead surrenders to the concept of constructive engagement, a 'normal' strategy defined by ASEAN.

For further research, it can be explained on factors of EU's policy to postpone the sanction. There are arguments from economists stating that EU can't lose the Myanmar business opportunities. Barrack Obama, the first sitting US president visited Myanmar, has lifted out the sanction and invited some US companies to invest in Myanmar. The Euro crisis and slowing global economy can also be consideration for the EU to postpone the sanction. It is also important to look at the continuation of the EU-ASEAN FTA negotiation.

\section{BIBLIOGRAPHY}

Abramowitz, M. \& Pickering, T., 2008. Making Intervention Work. Foreign Affairs, 87(5), pp.100-08.

AFP, 2012. Myanmar, Bangladesh leaders 'to discuss Rohingya'. [Online] Available at: HYPERLINK "http://www.google.com/ hostednews/afp/article/ALeqM5j7a3oPcHSvWSpkXzzSruvNZfdPMA?docld=CNG.8d52d8a6dba835c4ac54aab3f3c8031 b.571" http://www.google.com/hostednews/afp/article/ 
ALeqM5j7a3oPcHSwWSpkXzzSruvNZfdPMA?docld =CNG.8d52d8a6dba835c4ac54aab3f3c8031b.571 [Accessed 11 February 2013].

Bernama.com, 2007. EU puts Myanmar aside, proceeds FTA talks with ASEAN. [Online] Available at: HYPERLINK "http:// www.bernama.com/bernama/v3/news_lite.php?id=260077" http:// www.bernama.com/bernama/v3/news_lite.php?id $=260077$ [Accessed 13 February 2013].

Burma Campaign, U., 2004. The EU and Burma: Case for Targeted Sanction. London: Burma Campaign UK.

Burma Campaign, U., 2005. Total Oil: Fueling Opprresion in Burma. [Online] Available at: HYPERLINK "http:// www.burmacampaign.org.uk/index.php/news-and-reports/reports/ title/totalitarian-oil-total-oil-fuelling-the-oppression-in-burma" http://www.burmacampaign.org.uk/index.php/news-and-reports/ reports/title/totalitarian-oil-total-oil-fuelling-the-oppression-inburma [Accessed 6 February 2013].

Burma Campaign, U., 2012. Conclusion Analysis. [Online] Available at: HYPERLINK "http://www.burmacampaign.org.uk/index.php/newsand-reports/burma-briefing/title/analysis-of-eu-conclusions-onburma" http://www.burmacampaign.org.uk/index.php/news-andreports/burma-briefing/title/analysis-of-eu-conclusions-on-burma.

Centre, E.-A., 2006. A Qualitative Analysis of a Potential Free Trade Agreement between the EU and ASEAN. A Report prepared for the European Commission and the EU-ASEAN Vision Group. Limerick and Paris: Europe-Asia Centre, University of Limerick-IFRI.

Commission, E., 2006. Creating a new dynamic in EU-ASEAN relations. [Online] Available at: HYPERLINK "http://aei.pitt.edu/6271/" http:// aei.pitt.edu/6271/ [Accessed 13 February 2013].

Commission, E., 2013. ec.europa.eu/external_relations/myanmar/ intro/index.htm. [Online].

Cook, A., 2010. Positions of responsibility: A comparison of ASEAN and EU approaches toward Myanmar. International Politics, pp.433-49.

Council, E., 2007. Council Conclusions on Burma/Myanmar. [Online] European Council Available at: HYPERLINK "http:// www.consilium.europa.eu/ueDocs/cms_Data/docs/pressData/en/ gena/96525.pdf" http://www.consilium.europa.eu/ueDocs/ cms_Data/docs/pressData/en/gena/96525.pdf [Accessed 13 February 2013]

Council, E., 2013. Lisbon Treaty. [Online] Available at: HYPERLINK "http://europa.eu/lisbon_treaty/full_text/index_en.htm" http:// europa.eu/lisbon_treaty/full_text/index_en.htm [Accessed 6 February 2013].

Diez, T., 2005. Constructing the Self and Changing Others: Reconsidering 'Normative Power Europe'. Millennium - Journal of International Studies, 33, pp.613-36.

Diez, T., 2005. Constructing the Self and Changing Others: Reconsidering Normative Power Europe. Millenium - Journal of International Studies, pp.613-36.

Dosch, J., 2001. The ASEAN-EU Relations: An Emerging Pillar of the New International. In S. Chirathivat, F. Knipping, P. Lassen \& C.S. Yue, eds. Asia-Europe on the Eve of the 21st Century. Bangkok: Centre for European Studies at Chulalongkorn University. pp.43-56.

Eriksson, M., 2005. EU Sanctions: Three Cases of Targeted Sanction. In Wallensteen, P. \& Staibano, C. International Sanctions: Between words and wars in the global system. New York: Frank Cass. pp.108-25.

Factbook, C.W., 2013. Burma. [Online] Available at: HYPERLINK "https:/ /www.cia.gov/library/publications/the-world-factbook/geos/ bm.html" https://www.cia.gov/library/publications/the-worldfactbook/geos/bm.html [Accessed 13 February 2013].

Forsythe, D., 2000. Human Rights in International Relations. Cambridge: Cambridge University Press.

Fuller, T., 2012. Myanmar Military Admits to Airstrikes on Kachin Rebels. [Online] Available at: HYPERLINK "http://www.nytimes.com/ 2013/01/03/world/asia/myanmar-military-admits-air-raids-onkachin-rebels.html?_r=0" http://www.nytimes.com/2013/01/03/ world/asia/myanmar-military-admits-air-raids-on-kachinrebels.html?_r=0 [Accessed 13 February 2013].

Haacke, J., 2008. ASEAN and political change in Myanmar: towards a regional initiative? Contemporary Southeast Asia, 30(3), pp.35178.

Hettne, B., Söderbaum, F. \& Stålgren, P., 2008. The EU as Global Actor. Stockholm: Swedish Institute for European Policy Studies.

http://www. petersoninstitute.org/research/topics/sanctions/ myanmar.cfm, 2012. [Online].

Ismaïl, B., 2012. Burmese Media Spring. [Online] Reporters Without Borders Available at: HYPERLINK "http://en.rsf.org/birmanie-howlong-will-the-burmese-media-17-01-2013,43913.html" http:// en.rsf.org/birmanie-how-long-will-the-burmese-media-17-012013,43913.html [Accessed 13 February 2013].

Kettunen, E., 2004. Regionalism and the Geography of Trade Policies in EU-ASEAN Trade. Helsinki: Helsinki School of Economics.

Kittisereechai, P., 2008. The Democratic Uprising in Burma and the Response of ASEAN: Constructive Engagement, Neo-Liberalism and Their Failures. [Online] Available at: HYPERLINK "http:// www.psa.ac.uk/journals/pdf/5/2008/Kittisereechai.pdf" http:// www.psa.ac.uk/journals/pdf/5/2008/Kittisereechai.pdf [Accessed 13 February 2013].

Kreutz, J., 2005. Hard Measures by A Soft Power. Bonn: Bonn International Center for Conversion.

Kreutz, J., 2005. Hard Measures by a Soft Power: Sanctions Policy of the European Union 1981 - 2004. [Online] Available at: HYPERLINK "http://www.bicc.de/uploads/tx_bicctools/paper45.pdf" http:// www.bicc.de/uploads/tx_bicctools/paper45.pdf [Accessed 6 February 2013].

Kryvoi, Y., 2007. Why European Union Trade Sanctions Do Not Work. [Online] Available at: HYPERLINK "http://papers.ssrn.com/sol3/ papers.cfm?abstract_id=1007387" http://papers.ssrn.com/sol3/ papers.cfm?abstract_id=1007387 [Accessed 6 February 2013].

Linn, Z., 2012. Burma breaks reform promise, opens new offensive in Kachin State. [Online] Available at: HYPERLINK “http:// asiancorrespondent.com/93734/burma-breaks-reform-promise-byopening-new-offensive-in-kachin-frontline/" http:// asiancorrespondent.com/93734/burma-breaks-reform-promise-byopening-new-offensive-in-kachin-frontline/ [Accessed 12 February 2013].

Manner, I., 2002. Normative Power Europe: Contradiction in Terms. Journal of Common Market Studies, pp.235-58.

Manner, I., 2009. Normative Power Europe: A Transdisciplinary Approach to European Studies. In C. Rumfor, ed. The Sage Handbook of European Studies. London: Sage. 
Manners, I., 2008. The Normative Ethics of the European Union International Affairs, 84(1), pp.45-60.

Mukherjee, K., 2010. Is There a Distinct Style of Asian Democracy? Journal of Asian and African Studies, pp.684-94.

Nation, T., 2006. Burma political issue holding up EU-Asean free-trade talks. [Online] Available at: HYPERLINK "http:// nationmultimedia.com/2006/07/29/business/ business 30009860.ph" http://nationmultimedia.com/2006/07/ 29/business/business 30009860.php [Accessed 13 February 2013].

Nation, T., 2007. FTA with EU may cut Burma out. [Online] Available at: HYPERLINK "http://nationmultimedia.com/2007/02/09/business/ business 30026366.php" http://nationmultimedia.com/2007/02/ 09/business/business 30026366.php [Accessed 13 February 2013].

News, B., 2003. Do Sanctions Against Burma Work? [Online] Available at: HYPERLINK "http://news.bbc.co.uk/2/hi/asia-pacific/ 3006908.stm" http://news.bbc.co.uk/2/hi/asia-pacific/3006908.stm [Accessed 12 February 2013].

News, B., 2005. Burma will not take Asean chair. [Online] Available at: HYPERLINK "http://news.bbc.co.uk/2/hi/asia-pacific/4715283.stm" http://news.bbc.co.uk/2/hi/asia-pacific/4715283.stm [Accessed 13 February 2013].

Nicolaidis, K. \& Howse, R., 2002. 'This is my EUtopia ...': Narrative as Power. Journal of Common Market Studies, pp.767-92.

OECD, 2007. Aid Target Out of Slipping Reach? [Online] Available at: HYPERLINK "http://www.oecd.org/dataoecd/47/25/41724314.pdf " http://www.oecd.org/dataoecd/47/25/41724314.pdf [Accessed 6 February 2013].

Osman, S., 2005. Myanmar may not Chair ASEAN. Straits Times, 24 April.

Parliament, E., 2007. Resolution on Burma. [Online] Available at: HYPERLINK "http://www.europarl.europa.eu/oeil/popups/ ficheprocedure.do?id=553326" http://www.europarl.europa.eu/ oeil/popups/ficheprocedure.do?id=553326 [Accessed 13 February 2013].

Petersson, M., 2006. Myanmar in EU-ASEAN relations. Asia Europe Journal, 4(4), pp.563-81.

Robinson, G., 2012. Hague welcomes Myanmar's reform pledge. [Online] Available at: HYPERLINK "http://www.ft.com/cms/s/0/ 43291b36-3764-11e1-897b-00144feabdc0.html" V "axzz2KmDabrAz" http://www.ft.com/cms/s/0/43291b36-376411e1-897b-00144feabdc0.html\#axzz2KmDabrAz [Accessed 13 February 2013].

Robles, A., 2008. An EU-ASEAN FTA: The EU's Failures as an International Actor. European Foreign Affairs Review, 13, pp.541-60.

Rocher, S.B.d., 2012. The European Union, Burma/Myanmar and ASEAN: A challenge to European norms and values or new opportunity? Asia Europe Journal, 10, pp.165-80.

Sipri, 1996. Common Position on Burma/Myanmar 1996/635/CFSP. [Online] Available at: HYPERLINK "http://www.sipri.org/contents/ expcon/eu_burma1.html" http://www.sipri.org/contents/expcon/ eu burma1.html [Accessed 6 February 2013].

Sipri, 2000. Common Position 2000/346/CFSP. [Online] Available at: HYPERLINK "http://www.sipri.org/contents/expcon/ eu_burma2.html" http://www.sipri.org/contents/expcon/ eu_burma2.html [Accessed 6 February 2013].

Sipri, 2003. Common Position 2003/297/CFSP. [Online] Available at:
HYPERLINK "http://www.sipri.org/contents/expcon/ burma_embargo_2003_01.pdf." http://www.sipri.org/contents/ expcon/burma_embargo_2003_01.pdf. [Accessed 6 February 2013].

Sipri, 2004. Common Position 2004/423/CFSP. [Online] Available at: HYPERLINK "http://www.sipri.org/contents/expcon/ EUemb ren Burma2004.pdf" http://www.sipri.org/contents/ expcon/EUemb_ren_Burma2004.pdf [Accessed 6 February 2013].

Sipri, 2005. Common Position 2005/340/CFSP. [Online] Available at: HYPERLINK “http://www.sipri.org/contents/expcon/ burma_embargo_2005_01.pdf" http://www.sipri.org/contents/ expcon/burma_embargo_2005_01.pdf [Accessed 6 February 2013].

Sipri, 2007. Common Position 2007/750/CFSP. [Online] Available at: HYPERLINK "http://www.sipri.org/contents/expcon/ burma embargo 2007 01.pdf" http://www.sipri.org/contents/ expcon/burma_embargo_2007_01.pdf [Accessed 6 February 2013].

Sipri, 2012. Common Position 2012/225/CFSP. [Online] Available at: HYPERLINK “http://eur-lex.europa.eu/LexUriServ/ LexUriServ.do?uri=OJ:L:2012:115:0025:0026:EN:PDF" http://eurlex.europa.eu/LexUriServ/ LexUriServ.do?uri=OJ:L:2012:115:0025:0026:EN:PDF [Accessed 6 February 2013].

Smith, K., 2003. European Union Foreign Policy in A Changing World. Cambridge: Polity Press.

Tocci, N., Darbouche, H., Emerson, M. \& Fernandes, S., 2008. The European Union as a Normative Foreign Policy Actor. In N. Tocci, ed. Who is a Normative Foreign Policy Actor? The European Union and its Global. Brussels: Centre for European Policy Studies.

Watch, H.R., 2012. "The Government Could Have Stopped This" Sectarian Violence and Ensuing Abuses in Burma's Arakan State. [Online] Human Rights Watch Available at: HYPERLINK "http:// www.hrw.org/reports/2012/07/31/government-could-havestopped" http://www.hrw.org/reports/2012/07/31/governmentcould-have-stopped [Accessed 13 February 2013].

Watch, H.R., 2012. "Untold Miseries" Wartime Abuses and Forced Displacement in Burma's Kachin State. [Online] Human Rights Watch Available at: HYPERLINK "http://www.hrw.org/reports/2012/ 03/20/untold-miseries" http://www.hrw.org/reports/2012/03/20/ untold-miseries [Accessed 13 February 2013].

Whitman, R., 2011. Normative Power Europe: Empirical and Theoretical. Basingstoke: Palgrave MacMillan.

Yeo, S.b.A.C.S.M.f.F.A.G., 2007. Asean Secretariat. [Online] Available at: HYPERLINK "<http://www.aseansec.org/20974.htm" [Accessed 13 February 2013].

Zheng, H., 2012. Myanmar Conflict: Ethnic Discrimination in Rakhine State Sparks Violence Against Muslim Rohingya. [Online] Available at: HYPERLINK "https://www. policymic.com/articles/10025/ myanmar-conflict-ethnic-discrimination-in-rakhine-state-sparksviolence-against-muslim-rohingya" https://www. policymic.com/ articles/10025/myanmar-conflict-ethnic-discrimination-in-rakhinestate-sparks-violence-against-muslim-rohingya [Accessed 12 February 2013]. 